\title{
Viral Small RNA
}

National Cancer Institute

\section{Source}

National Cancer Institute. Viral Small RNA. NCI Thesaurus. Code C101143.

Small non-coding RNA that is encoded by viral DNA and transcribed by virally-infected cells. 